University of Wollongong

Research Online

Faculty of Social Sciences - Papers (Archive) Faculty of Arts, Social Sciences \& Humanities

2015

Maps and mobilities: On the possibilities and limits of spatial technologies for humanities research

Christopher R. Brennan-Horley

University of Wollongong, chrisbh@uow.edu.au

Follow this and additional works at: https://ro.uow.edu.au/sspapers

Part of the Education Commons, and the Social and Behavioral Sciences Commons

Research Online is the open access institutional repository for the University of Wollongong. For further information contact the UOW Library: research-pubs@uow.edu.au 


\title{
Maps and mobilities: On the possibilities and limits of spatial technologies for humanities research
}

\author{
Abstract \\ This paper explores the limits of spatial representation for understanding historic mobilities in a rural \\ Australian setting. For this research, an historical GIS was populated from paper map archives denoting \\ where and when bitumen roads were sealed in the Bega Valley, NSW. Using existing geospatial methods, \\ a temporally sensitive network analysis was conducted, revealing a picture of regional mobility reshaped \\ by modernist infrastructure improvements. Yet a straightforward binary pitting sealed roads as 'good' vs \\ unsealed roads as 'bad' was challenged in subsequent qualitative interviews with long-time residents. \\ Instead, a range of opinions emerged about the role that differing road surfaces played in everyday and \\ historic mobilities. A fuller picture of the motivations and cultural associations of bitumen vs dirt road \\ driving resulted from deploying humanities research methods of interviewing and discourse analysis. \\ Such an approach revealed preferences and motivations that sometimes challenged inferences gained \\ from mapping results alone. There are limits then in relying solely on historical cartographic data to \\ produce maps and spatial representations and existing humanities techniques may hold, in some \\ instances, greater explanatory power.
}

\section{Keywords}

possibilities, limits, technologies, maps, humanities, spatial, research, mobilities

\section{Disciplines}

Education | Social and Behavioral Sciences

\section{Publication Details}

Brennan-Horley, C. (2015). Maps and mobilities: On the possibilities and limits of spatial technologies for humanities research. International Journal of Humanities and Arts Computing, 9 (2), 242-261. 
Brennan-Horley, C (2015) 'Maps and Mobilities: On the possibilities and limits of spatial technologies for humanities research' International Journal of Humanities and Arts Computing 9:2, 242-261

\section{Abstract}

This paper explores the limits of spatial representation for understanding historic mobilities in a rural Australian setting. For this research, an historical GIS was populated from paper map archives denoting where and when bitumen roads were sealed in the Bega Valley, NSW. Using existing geospatial methods, a temporally sensitive network analysis was conducted, revealing a picture of regional mobility reshaped by modernist infrastructure improvements. Yet a straight forward binary pitting sealed roads as 'good' vs unsealed roads as 'bad' was challenged in subsequent qualitative interviews with long-time residents. Instead, a range of opinions emerged about the role that differing road surfaces played in everyday and historic mobilities. A fuller picture of the motivations and cultural associations of bitumen vs dirt road driving resulted from deploying humanities research methods of interviewing and discourse analysis. Such an approach revealed preferences and motivations that sometimes challenged inferences gained from mapping results alone. There are limits then in relying solely on historical cartographic data to produce maps and spatial representations and that existing humanities techniques may hold, in some instances, greater explanatory power.

\section{Keywords}

Historical GIS, network analysis, roads, transport, mobilities

\section{Contact email and mailing address:}

chrisbh@uow.edu.au

University of Wollongong

Wollongong NSW

Australia 2522 


\section{Introduction}

Fresh insights into past lives and cultures are possible as spatial information technologies become ever-more entwined with the humanities. Historical GIS (HGIS) are being constructed from an ever widening range of data sources including past censuses, cadastral and land use records, spatial text mining and georeferenced old maps, to name a few. Opening up these resources via locative attributes to GIS analysis offers tantalising possibilities to develop spatio-temporal data sets, compare qualitative and quantitative sources and attempt new visualisation strategies that sometimes challenge existing orthodoxies. ${ }^{1}$ Yet despite the possibilities, humanist scholars have also expressed reservations and critical appraisals of this burgeoning interest in spatial technologies, exposing epistemological issues and frictions when melding quantitative and statistical methods inherent to spatial analysis with humanities methods attuned to contingency and subjectivity. ${ }^{2}$

This article explores similar territory, tracing a research journey that began by building an HGIS on road sealing in one Australian region, with spatial analysis for mapping how rural automobility has altered in response to infrastructural evolution. However, what began as a relatively straightforward archival mapping and GIS analysis task, quickly morphed into mixed method research, with productive tensions emerging between cartographic outputs and more nuanced discourse analysis. In relaying this journey, with its problems, pitfalls and illuminations, I hope to illustrate how one predictive analytic tool might be applied retrospectively to historical infrastructure data, while also highlighting how qualitative methods provided a much needed counterpoint to spatial outputs.

In recent years, sociologists and geographers have expanded on static explanations of social and physical formations, incorporating movement as an equally significant force shaping identities and the geographies of everyday life. ${ }^{3}$ Important to this burgeoning mobilities field is a continuing focus on automobility, positioning the car within a socio-technical system with profound impacts on a range of domains, from public space and social relations, to spatial arrangements and images of

modernity. ${ }^{4}$ Beyond simply studying the motor vehicle, automobilities scholars seek to understand 
the complex systems of provision that enable fluid interconnection, with roads being a vital component of this wider system of automobility. As geographer Peter Merriman explains, "Roads and motorways have a history, they serve as familiar places for those that work in them and for commuters who repeatedly traverse them, and they enable and facilitate a broad array of mediated socio-material relations and entanglements" ${ }^{5}$ Vital then to any discussion of past and present geographies of automobility are the roads and tracks that facilitate travel.

This paper adds to this automobilities research agenda, by mapping and analysing the gradual emergence of sealed roads in a rural setting and discussing its effects with local residents. Relative to its urban counterparts, the comparatively slow emergence of bitumen in the case study locale presented an excellent means to investigate how infrastructure modernisation enacted time-space convergence in this rural locale. Donald Janelle first defined this phenomenon in 1968, describing "our shrinking world" mathematically, as transport innovations decrease travel time between places, making them appear closer together in time-space ${ }^{6}$. By reducing the friction of distance, time-space convergence has resulted in multi-scalar reshapings of economic and social possibilities.

\section{The Bega Valley as a case study region}

This research was conducted as part of a wider project on the sustainability of cultural life in three Australian country regions. ${ }^{7}$ In consultation with local Bega Valley residents, mobility was highlighted as a factor in sustaining social relations ${ }^{8}$. Road sealing was also discussed as a factor to be taken into account when making decisions about where and when to travel, with dirt road driving remaining an everyday experience for many local residents. The varied conditions under which automobility is made possible or hindered via road surface conditions warranted further inquiry, especially as many roads in the Bega Valley remain in a majority unsealed state.

The Bega Valley Local Government Area (Bega LGA) is located on the Far South Coast of New South Wales. European colonists arrived in the 1830 s, displacing the Indigenous owners of the Yuin- 
Monaro Nation ${ }^{9}$. Economic activity coalesced around Bega town, now the regional business centre servicing a handful of smaller towns and hamlets dotted amongst a range of rural, forested and coastal settings. The region maintains its place in the national psyche through its major export Bega Cheese - but its past reliance on dairying, forestry, whaling and fishing have waned since the $1970 s^{10}$. Successive waves of amenity-seeking migrants and retirees from the 1980 s onwards have contributed to a gradual diversification into tourism and service industries.

Looking at its mobility history, the Valley's coastal location guaranteed dominance for shipping of goods and passengers from the port towns of Eden, Bermagui, Merimbula and Tathra (Bega's nearest port). By the 1920s, in line with the explosive growth in everyday car use, automobile-based road transport began outcompeting passenger ship services, with the seafaring goods trade ceasing in the $1950 \mathrm{~s}^{11}$. A rail connection never breached the Great Dividing Range to the west, placing greater demand on road connections within and beyond the region. Australia's domestic car manufacturing industry matured after WWII, increasing the availability of vehicles designed specifically for Australian conditions ${ }^{12}$. By this time, hardened road surfaces such as bitumen and concrete were a feature of inner urban road networks, but its spread into regional areas was uneven.

At the time of writing, bitumen is by no means a ubiquitous feature, with 70 percent of the road network remaining unsealed (refer to Figure 1). Moving up the governance scale from private roads to State highways signals a greater prevalence of bitumen over dirt with all Primary roads in a sealed state (Princes and Snowy Mountains Hwy) and the majority of Arterial roads currently sealed. Despite increasing car travel from the 1950s onwards, the evolution of the Bega Valley's bituminised road network has been glacial in comparison to the state capital ${ }^{13}$. The Valley's low population density translates into an under-resourced local council reliant on state funds for road sealing and maintenance.

[Figure 1 here] 


\section{Reconstructing the history of Bega's sealed roads}

This research began with the aim of building an HGIS capable of charting the emergence of Bega's sealed roads from their beginnings to the present day distribution shown in Figure 1. It was hoped that first order geographic questions could be answered about where and when particular segments appeared. For example, did bitumen radiate out from a central point or did it emerge in a more piecemeal fashion? Were certain roads favoured over others? Once populated, the HGIS would then be open to spatio-temporal analysis.

The present day Bega Valley road network is markedly similar in layout and topology to that which existed in the 1930s. The main routes between towns, ostensibly the main roads, are assigned as Primary, Arterial and Sub-Arterial roads in the network hierarchy. These began solidifying into their current patterning by the early 1900s, in line with the advent of motor vehicles. At the State level, the creation of the Main Roads Board in 1925 saw funds apportioned for road improvements including sealing and realigning for main roads, but it would be many decades before the Bega Valley was to see its first fully sealed highway ${ }^{14}$. Since the 1930 s, energies were directed primarily at surface and realignment improvements rather than forging new road projects ${ }^{15}$. Prior to this time, roads developed in an ad hoc manner, tracing over existing Indigenous pathways and expanding bridle paths ${ }^{16}$. Early road construction and maintenance was sometimes a private affair, carried out by locals with scant road engineering experience or directives from government ${ }^{17}$. Apocryphal tales abound of roads too treacherous to attempt passage by night, and exhibiting a range of freeform repair strategies. ${ }^{18}$

Specific connections between towns solidified as sealing advanced, with priority given to Primary roads, the region's two highways (the Princes Highway, the main north/south connector and the Snowy Mountains Highway linking Bega westward to the Australian Capital Territory). Locally, new roads are constructed and sealed in residential subdivisions, in keeping with planning laws deflecting sealing costs to property developers, and small bypasses and realignments associated with road 
sealing on public road continue. However this research did not seek to reconstruct the minutiae of localised alterations and additions since the 1930s - many of which would not greatly impact cartographic display or analysis at the regional scale - rather, I sought to map the appearance of bitumen onto pre-existing dirt roads. The subsequent data search was reduced to uncover incidences of road sealing only from the 1930s onward, in order not to overlap with earlier times when many roads were under construction. ${ }^{19}$

A GIS file of the present day road network was provided by Bega Valley Shire Council, containing the spatial extent of the current sealed network and hierarchical categorisations. Unfortunately it did not include any sealing dates. Despite lacking in temporal sealing data, this shapefile formed the basis for the HGIS.

A range of textual and cartographic resources were searched for information about historic road sealing. Newspaper archives (microfiche and digital repositories), council minute books, local and state libraries, holdings at regional historical and genealogical societies, and map libraries held by UOW and the National Library of Australia each provided glimpses to the overall story. Yet a singular data set detailing exactly where and when bitumen appeared at regular intervals across the entire network was not forthcoming. This is due to the variety of jurisdictions including private landholders, government departments and various local councils who have had control of different parts of the network at different times in its history, each with diverse means for recording sealing status (if at all). State-controlled roads tend toward availability in cartographic form, whereas Bega Valley Shire Council kept written records in monthly minute books. ${ }^{20}$ While technically feasible, sifting through thousands of pages of council minutes and converting textual records into cartographic form fell beyond the scope of this project.

[Table 1 here] 
Despite this paucity of data, a partial cartographic record of the advancement of sealing was pieced together from an archive of State Road Authority maps, NRMA touring maps and topographic maps produced by the State Lands Department (detailed in Table 1). To add each map to the spatial database, each map was scanned at 300dpi and importing into ArcGIS as a jpeg image. Each image was then georeferenced against the road network shapefile. Each road segment was then visually inspected against each georeferenced historical map and its surface status recorded in the attribute table as either 'sealed' or 'unsealed' for that corresponding year.

[Figure 2 here]

A selection of this time series is given in Figure 2, charting progression of the bitumen network at approximately 20 year intervals upon primary and arterial roads. The first sealed road in the region, The Bega-Tathra Rd (ex-Snowy Mountains Highway) appeared in the historic map record in 1936, linking Bega to its coastal port. Passing through extensive river flats, sealing this road stemmed repeated damage from regular flooding, providing safer passage for freight to and from the Tathra Wharf. At this time the majority of freight transportation was still by sea, but faster automobile transport for public and private travel beyond the region had already spelled the demise of oceangoing passenger liners ${ }^{21}$.

The end of WWII saw an exponential increase in motor vehicle use in Australia for both freight and private transport ${ }^{22}$. Peak motoring group the NRMA (National Road Motorists Association) maintained pressure on all levels of government to commit funds to road sealing, but isolated regional areas such as the Bega Valley still lagged behind their urban counterparts. The opening of a Main Roads Board depot in Bega in 1951 permitted works to be carried out southwards from Bega rather than only adding to the existing sealed network from the north ${ }^{23}$. By the mid-1950s, bitumen continued its southward extension along the Princes Highway, where it was already sealed back to Sydney. 
The greatest amount of sealing took place over the next twenty years, with completion of a sealed surface to both the Princes and Snowy Mountains Highways. Not only did this herald a qualitative shift in the driving experience of local residents, but smoother and faster passage to the Far South Coast region was now possible for self-drive tourists ${ }^{24}$. Previously accessible only to locals or intrepid tourists who could handle the often slow and dusty unsealed road connections, the Bega Valley's seaside towns were now on the radar for influxes of seasonal travellers. Tourist towns became ever more prominent along the Bega Valley's coastal strip, with motels and caravan parks springing up to cater for seasonal demand. In a similar fashion to other towns along Australia's east coast, rural road sealing projects played a part in economic restructuring, broadening the range of business opportunities beyond primary production toward a service economy.

The rate of change to sealing of the primary and arterial network dropped off during the 1980s and 90s. Outliers included Mt Darragh Road which received state funding following public pressure for a sealed surface. This road was becoming a vital yet dangerous alternate east-west route whenever the Snowy Mountains Highway was blocked by landslips. Another main arterial link completed by the mid-1990s was the connection between Cobargo and the coastal town of Bermagui. First proposed for sealing some 20 years prior, a sealed connection to the northern coastal section was now available for travellers from the south and west, without detouring beyond the Shire - an important link strengthening Bermagui's emergence as a seaside tourist town and retiree haven ${ }^{25}$.

\section{From mapping road sealing to analysing travel}

As the previous section illustrates, historical maps acted as convenient visual aids when recounting histories of infrastructural change. Mapped over time, cartographic data on Bega's road network aided understanding of when sealed connections were made between towns and which routes were prioritised over others. This approach was not strictly spatial analysis per se, rather it simply collated and displayed spatial information from archival maps. After transferring the historical maps into a spatial data format, I wanted to explore the possibilities that spatial analysis might offer in 
understanding changes to travel patterns as the Bega Valley network selectively modernised. Analysing shifts in travel accessibility between towns over time seemed a plausible approach for mapping decreasing travel times as sealing expanded. In other words, could spatial analysis provide any insight into bitumen's capacity for time-space convergence?

Given that the roads data was structured as a system of links and nodes, spatial network analysis appeared the most applicable toolset. Building off theoretical foundations in graph theory and topology, spatial network analysis has become increasingly common practice in transport geography and urban planning, for understanding network centrality, modelling travel demand and as an input into multi-criteria site selection problems. A common subset of network analysis involves delineating service areas or drive-time catchments for a new facility. The outputs of service area analysis, known as isochrones, represent zones of equal travel time radiating away from an assigned centre. Service area analysis appeared relevant for mapping changing one hour drive-time catchments from the Bega town centre out into the hinterland as the sealed network evolved.

Key to this network analysis approach would be modelling with GIS the difference in driving experience between sealed and unsealed roads. Sealed roads represent a marked decrease in surface variability over dirt roads with the latter being notoriously slippery, especially for two-wheel drive vehicles. Dirt roads degrade daily in response to traffic volumes, vehicle weight and weather events. Cautious driving techniques are often required to pick a path through ever-changing potholed and corrugated sections, making the average dirt road driving experience in the Bega Valley much slower than traversing the same distance on bitumen. Hence, speed increases would represent a proxy measure in the network model of the change from dirt to bitumen. ArcGIS Network Analyst Extension permits the addition of speed as a cost attribute to specified sections of the network. Table 2 lists the various speeds input into this historical network model across the three time periods, taking into account each road's position within the hierarchy alongside speed regulations of the time. 
Network analysis can simulate travel scenarios under a range of conditions but in order to build a more realistic model, data about the entire network's sealed status - from primary roads to farm tracks - at a given point in time was required. As discussed previously, a detailed year-to-year time series was out of reach, but three time periods were identified that provided an accurate depiction of the entire network's sealed status: An early-sealed scenario (1936) a 1975 edition of the 1:25000 topographic map series covering the region and Council's road shapefile (2011). ${ }^{26}$

[Table 2 here]

\section{Service area analysis results}

Figure 3 maps the result of the service area analysis, displaying isochrones for drive times in one hour increments for the three time periods of the 1930s, 1970s and present day. Most prominently the service area analysis illustrates a vast increase in travel potential by the time the 1970 s sealing extent was reached. Efforts made over the previous half century in sealing primary and arterial routes had the effect of decreasing travel times to and from Bega for the majority of the Valley's population. By the 1970s the stage had been set for transport times now experienced with only a minor increase in travel potential between the 1970s and the present day. This is due in part to a drop in speed restrictions from 60 to $50 \mathrm{~km} / \mathrm{hr}$ within towns which is not greatly counteracted by the raising of speed limits by $20 \mathrm{~km} / \mathrm{hr}$ on open roads. Even though more sealing has been completed within the urban areas of towns, regulation has decreased propensity for faster travel in these zones.

[Figure 3 here]

At face value the network analysis appears to support the case that at the regional scale, bitumen has enacted time-space convergence for motorists of the Bega Valley with a greater number of towns drawn into a plausible daily commuting catchment of the regional business centre. From the 1930s onwards, as bitumen became more prominent, time-space convergence has reshaped 
everyday life and relations between towns. Anecdotes and informal discussions with local residents who commute daily into Bega from the Shire's northern outskirts were in line with the map's isochrones. Accessing Bega's employment opportunities and services on a daily basis is a regular occurrence for these residents. Additionally, shopping habits have adapted in line with the spatial reorganisation of food retailing. ${ }^{27}$ Increasing levels of accessibility mean that most foodstuffs are no longer sourced locally and delivered to residents. Rather, daily commuting patterns into larger centres to collect food are the norm, with grocery retailers reliant less on local produce but by wider goods networks emanating from larger distribution centres beyond the Valley. These large supermarket chains are themselves predicated on efficient bitumen road links to and from the region.

Time-space conversion through bitumen is a two-way relationship, with bitumen not only affording a gravitational pull to the centre, but underpinning stable populations in hamlets and towns at a distance. Originally settled as district centres servicing nearby farming communities, farm mechanisation and declining employment in forestry and fishing fuelled rural-urban migration from the Bega Valley since the $1950 \mathrm{~s}^{28}$. Successive waves of amenity-led and retiree migration from the late 1970 s onwards has underpinned the viability of some local towns. But lifestyles in these outer districts are now predicated on automobile travel over greater distances to access centralised employment opportunities and services ${ }^{29}$. Ironically, many amenity migrants from the cities are conditioned to long commutes in terms of travel time, but are happy to travel for similar lengths of time with little to no traffic issues.

\section{A fork in the road: confronting cartographic limitations}

Upon completing the service area analysis, I was faced with a choice: continue down a spatial analysis route or compare the mapping outputs with alternate sources that also speak to impacts of road sealing - albeit data not in a form readily capable of integration into the spatial database. 
Prior to deciding, further spatial analysis possibilities were reviewed, including tweaking existing network parameters (turn impedances, adding bridges) and modelling differential speed limits for two wheel vs four wheel drive. Given that the existing analysis was conducted in a flat plane I looked at incorporating terrain modelling, particularly as hilly areas necessitate more careful dirt road driving tactics. Other more advanced map-based strategies were also considered, including time space maps which swap linear topographic and time units, producing a time-based cartogram. Three dimensional accessibility surfaces presented yet another avenue, by displaying more accessible zones as higher 3D peaks.

Despite investigating these additional possibilities, the analysis given in Figure 3 had illustrated that increasing levels of bitumen might enact time-space convergence, leaving me hesitant as to what could be gained in refining the spatial analysis. Furthermore, there is an inherent tension working with HGIS, whereby an overt focus on cartographic strategies can direct attention away from deeper contextualisation while masking possible open-ended contingency. ${ }^{30}$ No matter how finely tuned or snappily displayed, attempting to recreate 'real world' driving scenarios with spatial analysis techniques would only provide partial insight. As cultural geographer Tim Creswell argues, "...there are pervading constellations of mobility, particular patterns of movement, representations of movement, and ways of practising movement that make sense together."${ }^{31}$ Despite moving away from a strictly spatial approach, understanding some of the more subjective, cultural dimensions of driving would provide a more rounded view of the impact of a changing road network.

To unveil driving practices I turned to qualitative, semi-structured interviews with a select group of local residents, alongside unsolicited and anecdotal discussions with acquaintances living in the Bega Valley. The strengths of qualitative investigation, of thick description, depth and context, permitted a range of quotidian interactions between actual drivers and variable road conditions to emerge. Attitudes toward dirt and bitumen roads were revealed, including routing choices and driving behaviours made in response to differing surfaces and how driving practices become shaped by a 
lifetime of experiences behind the wheel. From wide-ranging discussions, themes of safety and routing emerged as most relevant to considerations of temporal change to the bitumen network.

Sealed roads are regularly represented as a safer alternative to dirt roads ${ }^{32}$. Smooth surfaces, cambered corners, dividing lines and reflectors all enhance driver safety ${ }^{33}$. Unsurprisingly, safety was a recurrent theme in discussions about driving upon different surfaces. Many of those interviewed agreed that bitumen was a safer place to travel than dirt roads. Some were not overly fond of dirt road driving and spoke of incessant dust, the uncomfortable driving experience and the extra effort required in steering a course over an ever-changing surface. Fears were expressed around facing oncoming traffic on often narrow and slippery corners with little or no road shoulder, of sliding or getting bogged during wet weather.

Yet how different surfaces were perceived did not always fit neatly into a binary of sealed roads as safe vs unsealed as unsafe. Upon reflection, some respondents positioned dirt roads not as fearful spaces but enjoyable places to drive, even if it meant a slower journey. Dirt roads were positioned by some as natural, an extension of untamed forested landscapes that held mystery and wonder and could be a space for recreational driving. Dirt roads were seen by others as an expected element of the transport landscape, and part of everyday life in a rural locale. A hardship not simply to be endured, but a point of difference from other drivers restricting themselves to bitumen.

Of relevance to this study, was how the road network was negotiated 'safely' in diverse ways at different times. Stories were relayed of drivers sneaking past possible police detection by detouring along dirt back roads after a night out. After dusk, one participant spoke of dirt roads as a place to escape from other drivers travelling at excessive speeds on the bitumen. The dirt road was conversely viewed as a place of relative safety, where one could travel with less fear of collision. Route choices were influenced by notions of safety, but these may not fall out in a simplistic manner but were inflected by individual driving experiences and preferences. 
Unlike the mapping algorithm, which modelled the driver as a rational decision maker looking to minimise travel time between two points, interviews revealed that drivers consider multiple factors when deciding upon a route. These decisions can be tempered by a range of emotional and bodily reactions to past driving scenarios, either positive or negative. Apart from safety, other factors influencing routing decisions included considerations of time constraints, vehicle type, vehicle wear and tear, dust potential, and recent road conditions. This meant that sometimes dirt roads were avoided in favour of a longer sealed road route. Time became a less important factor than a smoother, faster (in terms of travelling speed) and uneventful bitumen road journey. These drivers placed personal comfort ahead of shorter travel time.

\section{Conclusion}

This paper sought to highlight both the possibilities and limits that service area analysis might provide historical mobilities research. GIS collation and visualisation was applied to a corpus of historical infrastructure data, illustrating the emergence of sealed roads over time. Despite facing an incomplete temporal data set, hypothetical drive-time isochrones were generated using facility area analysis, with travel speed as a proxy for changing surface conditions.

Mapping broad changes in travel times between towns was made possible via this spatial approach, and may prove useful for mobilities researchers looking to spatially represent evolving transportation networks and resultant time-space convergence, especially those modes that run to timetables such as trains or airport networks. This approach may also be particularly applicable for HGIS projects operating at large scales, for example, charting the emergence over time of rail or highway networks at the state and national level. Further applications could include melding service area isochrones with cadastral records in GIS to reveal possible path-dependent evolution of land subdivision and evolving mobility networks. 
Yet wherever historic transport and mobility studies intersect with private vehicle usage at the regional and local scale, the role that personal choice plays in shaping spatial patterns of automobility cannot be ignored. For this research, qualitative methods were turned to, principally because successive rounds of GIS mapping and analysis remained silent about the motivations and experiences of actual car drivers.

Subsequent interviews and discussions revealed that driving upon different surfaces elicited a range of reactions, with these in turn shaping individual choices about when and where to travel.

Whenever personal choice is involved, time-space convergence is perhaps not as straightforward as quantitative mapping algorithms might suggest. Furthermore, perceptions of travel time were inflected by surface conditions but in ways that sometimes challenged taken for granted assumptions representing sealed roads as the safer option.

Rather than assuming that all people drive the same way, conforming only to legislated speed restrictions, qualitative inquiry uncovered a broader range of driving experiences and motivations beyond the purview of historic maps and spatial analysis. Personal routing choices matter and exert spatio-temporal impacts on mobility. These choices are modulated by drivers balancing out any number of competing and often subjective factors, many borne from past driving experiences. If one was to attempt to map subjective travel potentials cartographically, variegated isochrones representing travel patterns of different respondents would undoubtedly result. Future research could look to mental mapping and Qualitative GIS techniques to investigate this further.

Qualitative insights have implications for how we should interpret mapping outputs s from this HGIS analysis of automobile travel potentials. Foremost, they should be viewed as exactly that - a mapping of an upper limit of possibility based only on time, rather than an amalgam of individual driving experiences. But this should not be grounds for dismissing the network analysis. Indeed for some travel upon the network - especially that between towns where bitumen was the most direct and fastest possible route - the spatial analysis holds true. The qualitative findings provide a window 
into the range of driving practices carried out by drivers facing choices about where and when to travel upon differing road surfaces. By extension, time-space convergence was experienced subjectively as the Bega Valley bitumen network developed.

Echoing the words of lan Gregory, GIS and spatial analyses are at best "broad brush" awaiting complementary insights from existing humanities methods. ${ }^{34}$ As was the case in this research, some data sources were difficult to encapsulate within the strictures of a geospatial database. Yet these are necessary in fleshing out details of driving practices. If GIS is to only offer "a radically incomplete account of everyday life in public space ${ }^{\prime 35}$ then humanists must remain open to existing methods that may present complementary or divergent results. In the wider digital humanities, spatial and qualitative approaches will both remain necessary, albeit topic and data dependant. The challenge lies in working productively with the confines and prospects of each. 


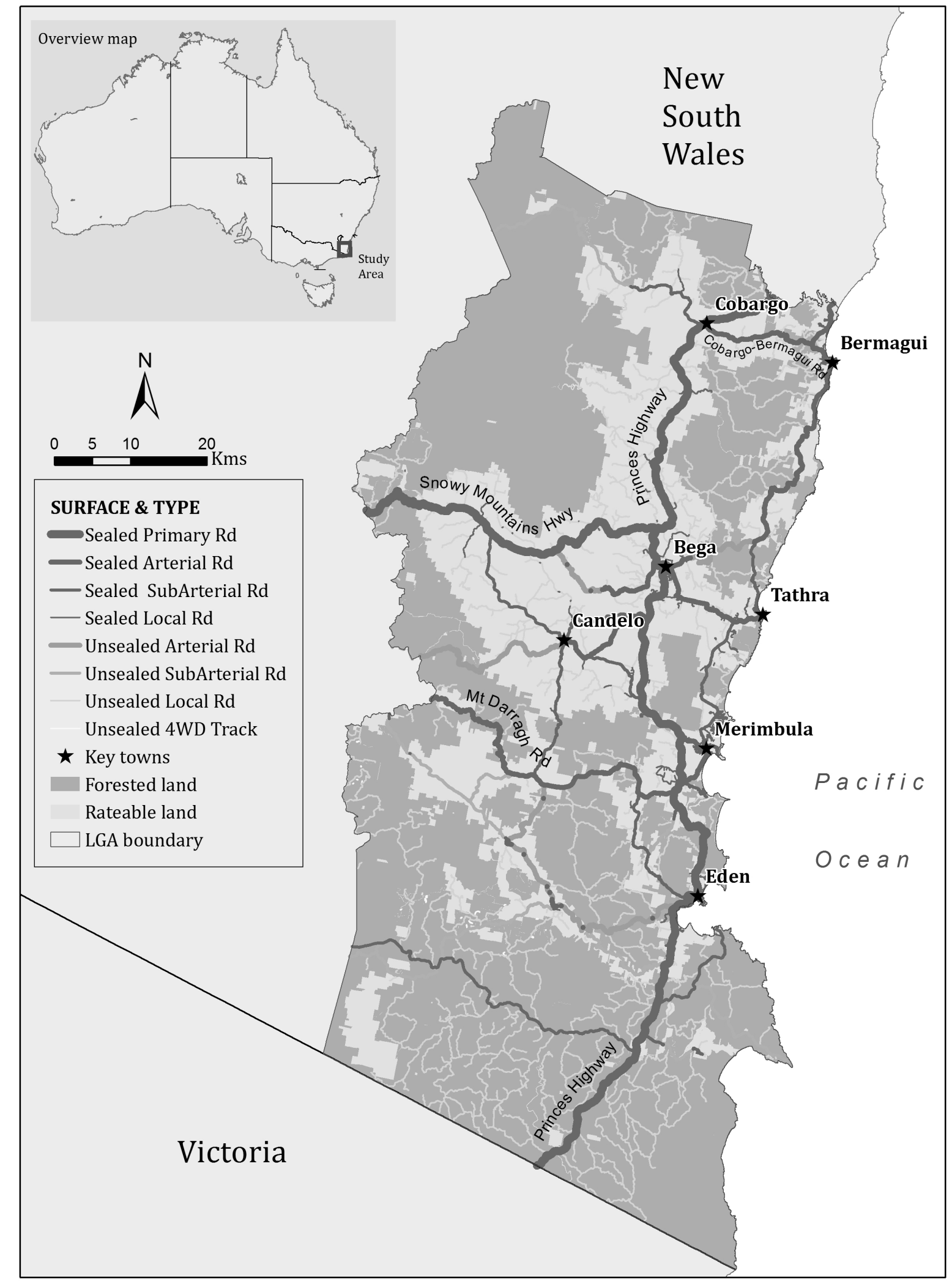

Figure 1: Bega Valley location map incorporating road sealing status, 2011 


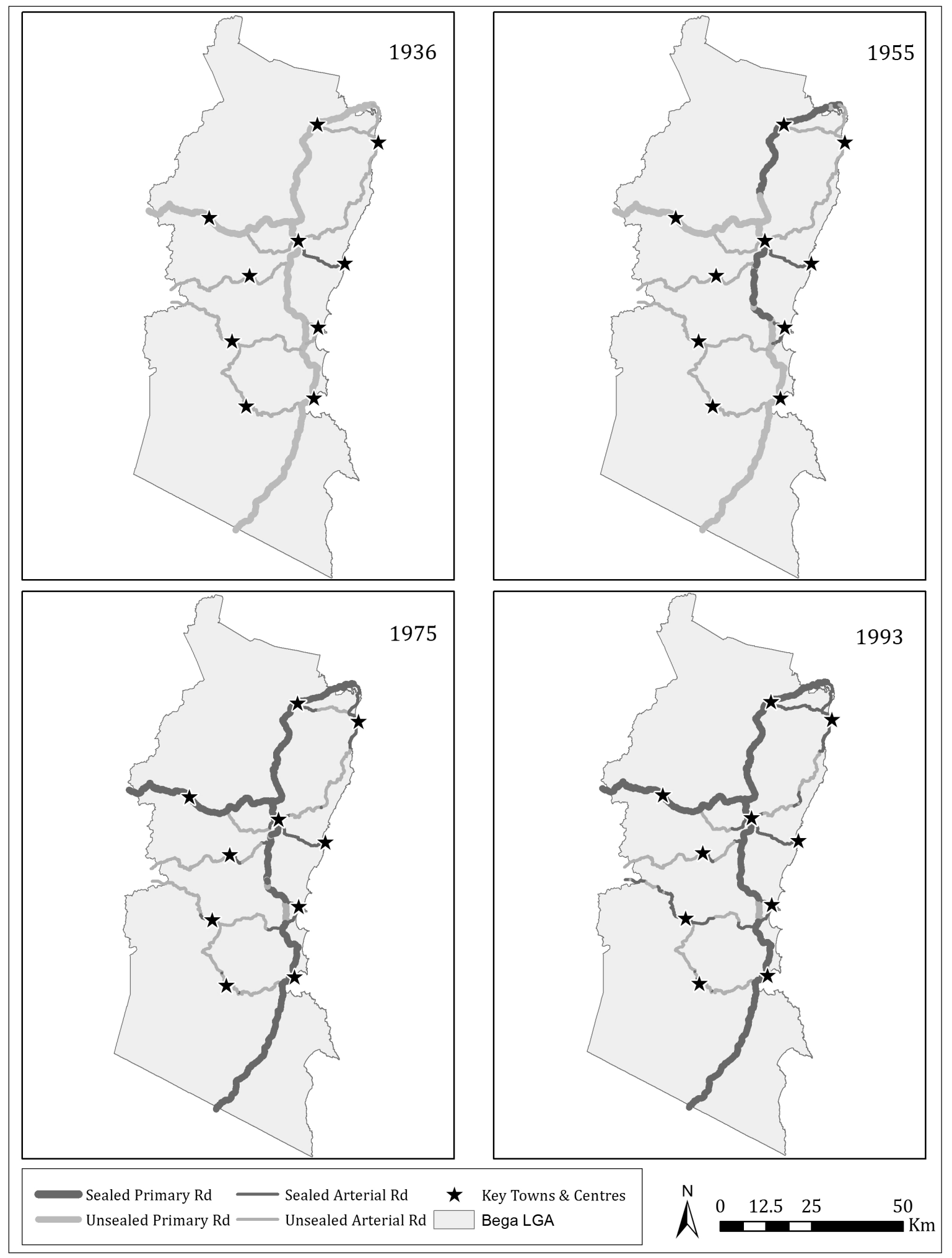

Figure 2: Advancement of sealed main State Road network at approximately 20 year intervals 1936 1993. Each map created from an amalgam of data up to and including the date provided in the top 
corner of each frame, but stylised to show only State-owned roads. Refer to Table 1 for corresponding years and to Figure 1 for extent of most recent sealing data (2011). 


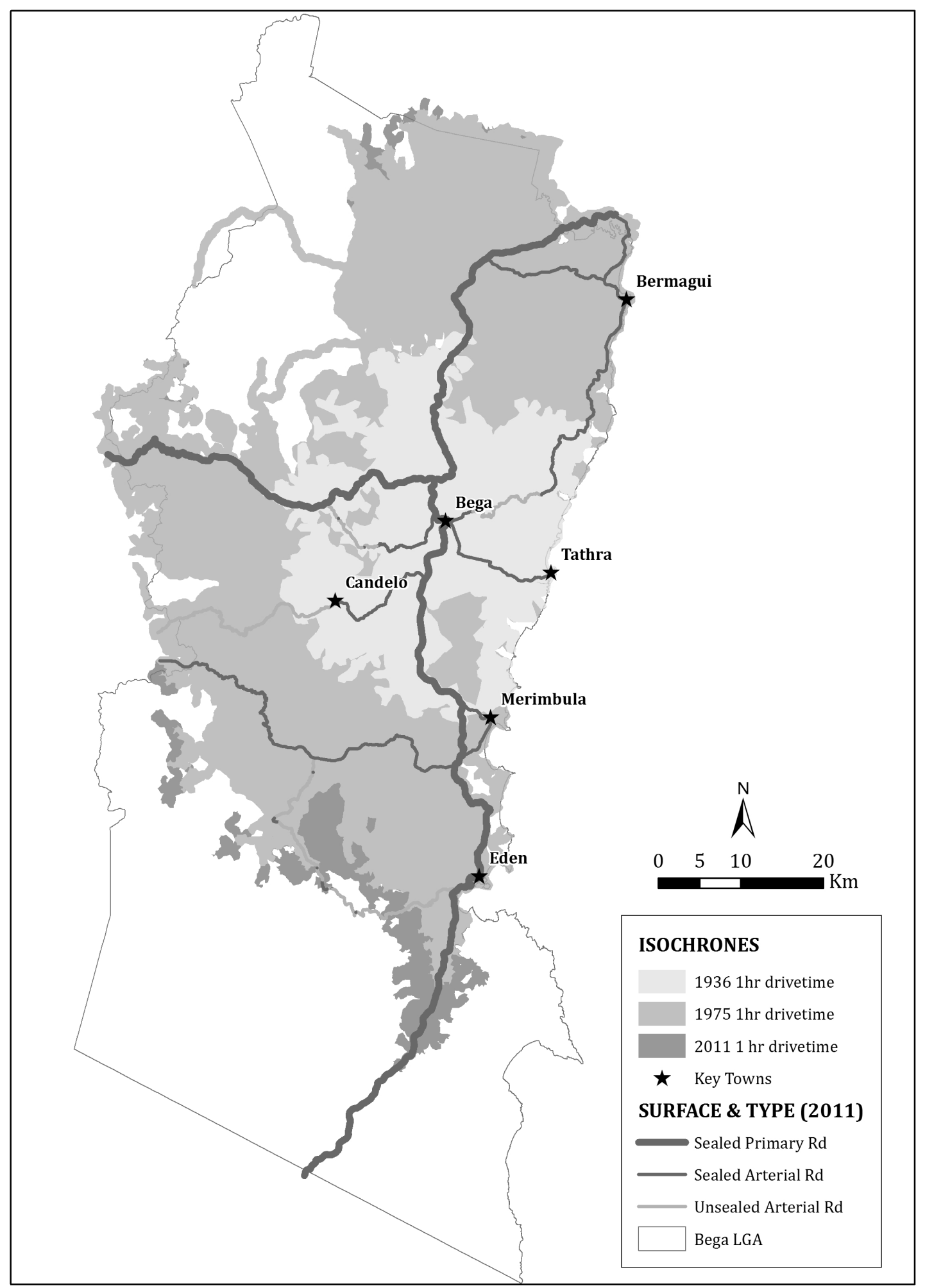

Figure 3: 1 hour drive time isochrones from Bega, 1936-2011 
Table 1: Maps and datasets detailing Bega Valley sealing extent, 1936-2011

\begin{tabular}{|c|c|c|c|c|}
\hline YEAR & MAP TITLE & SHEET COUNT & PUBLISHER & ROAD HIERARCHY \\
\hline $1936^{*^{+}}$ & $\begin{array}{l}\text { Types of surface on } \\
\text { main roads in New } \\
\text { South Wales }\end{array}$ & 1 & $\begin{array}{l}\text { Department of Main } \\
\text { Roads }\end{array}$ & Primary, Arterial \\
\hline 1942 & $\begin{array}{l}\text { Bega, New South } \\
\text { Wales } \\
\end{array}$ & 1 & $\begin{array}{l}\text { AHQ Cartographic } \\
\text { Company }\end{array}$ & Primary, Arterial \\
\hline 1947 & $\begin{array}{l}\text { Types of surface on } \\
\text { main roads in New } \\
\text { South Wales }\end{array}$ & 1 & $\begin{array}{l}\text { Department of Main } \\
\text { Roads }\end{array}$ & Primary, Arterial \\
\hline $1955^{*}$ & $\begin{array}{l}\text { Types of surface on } \\
\text { main roads in New } \\
\text { South Wales }\end{array}$ & 1 & $\begin{array}{l}\text { Department of Main } \\
\text { Roads }\end{array}$ & Primary, Arterial \\
\hline 1960 & $\begin{array}{l}\text { Types of surface on } \\
\text { main roads in New } \\
\text { South Wales }\end{array}$ & 1 & $\begin{array}{l}\text { Department of Main } \\
\text { Roads }\end{array}$ & Primary, Arterial \\
\hline 1961 & $\begin{array}{l}\text { Types of surface on } \\
\text { main roads in New } \\
\text { South Wales }\end{array}$ & 1 & $\begin{array}{l}\text { Department of Main } \\
\text { Roads }\end{array}$ & Primary, Arterial \\
\hline 1963 & $\begin{array}{l}\text { Types of surface on } \\
\text { main roads in New } \\
\text { South Wales }\end{array}$ & 1 & $\begin{array}{l}\text { Department of Main } \\
\text { Roads }\end{array}$ & Primary, Arterial \\
\hline 1964 & $\begin{array}{l}\text { Types of surface on } \\
\text { main roads in New } \\
\text { South Wales }\end{array}$ & 1 & $\begin{array}{l}\text { Department of Main } \\
\text { Roads }\end{array}$ & Primary, Arterial \\
\hline 1965 & $\begin{array}{l}\text { Types of surface on } \\
\text { main roads in New } \\
\text { South Wales }\end{array}$ & 1 & $\begin{array}{l}\text { Department of Main } \\
\text { roads }\end{array}$ & Primary, Arterial \\
\hline 1967 & $\begin{array}{l}\text { Types of surface on } \\
\text { main roads in New } \\
\text { South Wales }\end{array}$ & 1 & $\begin{array}{l}\text { Department of Main } \\
\text { Roads }\end{array}$ & Primary, Arterial \\
\hline 1969 & $\begin{array}{l}\text { Types of surface on } \\
\text { main roads in New } \\
\text { South Wales South } \\
\text { East Region }\end{array}$ & 1 & $\begin{array}{l}\text { Department of Main } \\
\text { Roads }\end{array}$ & Primary, Arterial \\
\hline $1975^{*^{+}}$ & $\begin{array}{l}\text { New South Wales, } \\
\text { Australia } 1: 25000 \\
\text { Topographic map } \\
\left.\text { series ( } 2^{\text {nd }} \text { edition }\right)\end{array}$ & 25 & $\begin{array}{l}\text { Central Mapping } \\
\text { Authority }\end{array}$ & $\begin{array}{l}\text { Primary, Arterial, } \\
\text { Sub arterial, Local, } \\
\text { Vehicular track }\end{array}$ \\
\hline 1981 & $\begin{array}{l}\text { South Coast and } \\
\text { Snowy Mountains }\end{array}$ & 1 & $\begin{array}{l}\text { National Roads and } \\
\text { Motorists } \\
\text { Association }\end{array}$ & $\begin{array}{l}\text { Primary, Arterial, } \\
\text { Sub arterial }\end{array}$ \\
\hline 1988 & $\begin{array}{l}\text { Types of surface on } \\
\text { main roads in New } \\
\text { South Wales }\end{array}$ & 1 & $\begin{array}{l}\text { Roads and Traffic } \\
\text { Authority }\end{array}$ & Primary, Arterial \\
\hline 1993* & $\begin{array}{l}\text { South Coast and } \\
\text { Snowy Mountains }\end{array}$ & 1 & $\begin{array}{l}\text { National Roads and } \\
\text { Motorists } \\
\text { Association }\end{array}$ & $\begin{array}{l}\text { Primary, Arterial, } \\
\text { Sub arterial }\end{array}$ \\
\hline 2001 & $\begin{array}{l}\text { New South Wales, } \\
\text { Australia 1:25000 }\end{array}$ & 25 & $\begin{array}{l}\text { NSW Department of } \\
\text { Lands }\end{array}$ & $\begin{array}{l}\text { Primary, Arterial, } \\
\text { Sub arterial, Local, }\end{array}$ \\
\hline
\end{tabular}




\begin{tabular}{|l|l|l|l|l|}
\hline & $\begin{array}{l}\text { Topographic map } \\
\text { series }\left(2^{\text {nd }} \text { edition) }\right.\end{array}$ & & & Vehicular track \\
\hline $201 *^{*^{+}}$ & Untitled & N/A & $\begin{array}{l}\text { Bega Valley Council } \\
\text { spatial database, } \\
\text { road network extract }\end{array}$ & $\begin{array}{l}\text { Primary, Arterial, } \\
\text { Sub arterial, Local, } \\
\text { Vehicular track }\end{array}$ \\
\hline
\end{tabular}

* Used in time series mapping detailed in Figure 2

${ }^{+}$Input layer for service area analysis shown in Figure 3 
Table 2: Bega Valley functional road hierarchy by speed and year

\begin{tabular}{|c|c|c|c|c|c|c|c|c|c|}
\hline \multicolumn{10}{|c|}{ SPEED AND TYPE } \\
\hline & \multicolumn{2}{|c|}{$\begin{array}{l}\text { Primary } \\
\text { (km/hr) }\end{array}$} & \multicolumn{2}{|c|}{$\begin{array}{l}\text { Arterial } \\
\text { (km/hr) }\end{array}$} & \multicolumn{2}{|c|}{$\begin{array}{l}\text { Sub-arterial } \\
\qquad(\mathrm{km} / \mathrm{hr})\end{array}$} & \multicolumn{2}{|c|}{$\begin{array}{l}\text { Local } \\
\text { (km/hr) }\end{array}$} & $\begin{array}{l}\text { Vehicular } \\
\text { track } \\
(\mathrm{km} / \mathrm{hr})\end{array}$ \\
\hline YEAR & sealed & unsealed & sealed & unsealed & sealed & unsealed & sealed & unsealed & unsealed \\
\hline 1936 & - & 50 & 80 & 50 & 50 & 50 & - & 50 & 30 \\
\hline 1975 & 80 & 50 & $80 / 60$ & 50 & $80 / 60$ & 50 & $60 *$ & 50 & 30 \\
\hline 2011 & 100 & - & $100 / 80 / 60 *$ & 50 & $100 / 80 / 60 *$ & 50 & 50 & 50 & 30 \\
\hline
\end{tabular}

*Two important changes to state speed restrictions were incorporated into the model. In 1979, open road speed limits were increased from $80 \mathrm{~km} / \mathrm{hr}$ to $100 \mathrm{~km} / \mathrm{hr}$. In 2003, default urban speed limits were decreased from $60 \mathrm{~km} / \mathrm{hr}$ to $50 \mathrm{~km} / \mathrm{hr}$. 


\section{END NOTES}

${ }^{1}$ I. Gregory, and R. Healey, 'Historical GIS: Structuring, Mapping and Analysing Geographies of the Past', Progress in Human Geography 31 (2007), 638-53.

${ }^{2} A$ range of engagements with the spatial humanities field are evident in recent edited collections including: A. von Lunen and C. Travis, eds, History and GIS: Epistemologies, Considerations and Reflections, (United States 2012) and D. Bodenhamer, J. Corrigan, and T. Harris, eds, The Spatial Humanities: GIS and the Future of Humanities Scholarship, (Indiana 2010). Journal articles critically appraising GIS within the context of historical research projects include: L. Espinha da Silveira, 'Geographic Information Systems and Historical Research: An Appraisal', International Journal of Humanities and Arts Computing 8, (2014), 28-45 and K. Bowles, 'Limit of Maps? Locality and Cinemagoing in Australia', Media International Australia 131 (2009), 83-94.

${ }^{3}$ T. Cresswell, 'Mobilities I: Catching up', Progress in Human Geography 35 (2010), 550-58.

4 J. Urry, 'The "System" of Automobility', Theory, Culture \& Society 21 (2004), 25-39.

${ }^{5}$ P. Merriman, 'Automobility and the Geographies of the Car', Geography Compass 3 (2009), 586-99. Quoted here at 589.

${ }^{6}$ D. Janelle , 'Central place development in a timespace framework, The Professional Geographer 20 (1958), Quoted here at 351.

${ }^{7}$ Australian Research Council Discovery Grant, 'Cultural sustainability in Australian country towns: amenity, mobility, and everyday life'. 2009-2011 (DP0984223).

${ }^{8} 46$ Local community members (age range $30-75$ ) attended a meeting to canvas important cultural research topics. Further research activities resulted, as detailed in G. Waitt and C. Gibson, 'The Spiral Gallery: Nonmarket creativity and belonging in an Australian country town', Journal of Rural Studies 30 (2013), 75 -85.

${ }^{9}$ N. Evans, Tales of the Far South Coast (Bega, 1982).

${ }^{10}$ Waitt,'Spiral Gallery' Journal of Rural Studies.

${ }^{11}$ N. Evans, Roads to Water: the history and story of Tathra, Kalaru, Wallagoot (Kalaru, 1987).

${ }^{12}$ R. Lee, Linking a nation Australia's transport and communications 1788-1970. (Canberra, 2003). 
${ }^{13}$ An example of the disparities in road development between rural and urban regions of NSW is evidenced in the opening of the Cahill expressway - Sydney's first multi-lane freeway - in 1962 a full two years prior to the Bega Valley's Princes highway becoming fully sealed. Detailed in Lee, Linking a nation.

${ }^{14}$ Prior to the advent of the Main Roads Board in 1925, all the Bega Valley's public roads fell under municipal control. Post 1925, main and arterial roads passed over to control of the Main Roads Board. Kass, T, Roads and Traffic Authority Heritage and Conservation Register: Thematic History (Sydney 2006).

${ }^{15}$ The archival map search did not return cartographic data on the full study area road hierarchy for the 1930 s. Upon reviewing council minutes and yearly journals issued by the Department of Main roads between 1920 and 1975 , all discussions of main and arterial roads in the study region were in reference to maintenance and sealing as opposed to initial construction.

${ }^{16}$ J. Blay Report of the Bega Valley Region Old Path Ways And Trails Mapping Project (Bega, 2005). Also noted in Kass, RTA thematic history.

${ }^{17}$ Bega District News, W.H. Balmain looks back: 50 years of Balmain bros. Bega Limited (Bega, 1959).

18 "Alexander Weatherhead on a trip from Wyndham to Bega in the late forties contributes another picture of the times, "I saw a man mending some of the worst places by putting bushes in the holes and then covering them with earth, so that it looked better till a heavy load came along. One always expects to see things better as they come towards a town, in that I was not disappointed, at least I saw that they had a different way of filling up the bog holes. There was then a nasty hole on the south side where Frog's Hollow bridge is now, when I got there the hole was filled up, not with bushes, but with a dead bullock, a worker, I suppose, it appeared to fill the hole nicely."' 'Historical Roads of New South Wales "Princes Hwy"', Journal of Department of Main Roads, New South Wales 16 (1951). Quoted here at 82.

${ }^{19}$ This decision to restrict searching was influenced by the fact that the first sealing did not appear in the Bega Valley until the 1930s.

${ }^{20}$ Bega Valley Shire Council formed in 1981 via amalgamation of three prior councils: Mumbulla Shire Council (1907), Bega Municipal Council (1885) and Imlay Shire Council (1907). Of interest to 
this research, the Australian Local Government System has its roots in establishing a tax base to fund road construction and maintenance, particularly in regional and rural locales.

${ }^{21}$ Evans, Roads to Water.

${ }^{22}$ Lee, Linking a nation.

${ }^{23}$ Department of Main Roads Journal of Department of Main Roads, New South Wales 16.

${ }^{24}$ Ferguson, B. A short history of Merimbula (Merimbula 1971).

${ }^{25}$ Bega Valley Shire Council, Your Place - Our Place: Character profiles for towns and villages of the Bega Valley Shire (Bega, 2002).

${ }^{26}$ The 1973 1:25000 data series consisted of multiple map sheets with a high degree of horizontal accuracy (12.5 metres) with the sealed or unsealed state of the entire road hierarchy provided. Each paper map was georeferenced and sealed status assigned to corresponding sealed sections. Each sealed segment was assigned its relevant maximum speed as listed in Table 2.

${ }^{27}$ D. Janelle, 'Spatial reorganisation: a model and concept', Annals of the Association of American Geographers 59 (1969), 348-64

${ }^{28}$ Hanson, S, "Electrical Wonders of the Present Age: Cinema-going on the Far South Coast of NSW and rural perceptions of modernity (Unpublished Honours Thesis, UOW Arts Faculty, 2007).

${ }^{29}$ Bega Valley Shire Council, Your Place - Our Place.

${ }^{30}$ S. Griffiths, 'GIS and Research Into Historical "Spaces of Practice": Overcoming the Epistemological Barriers', in A. von Lunen and C. Travis, eds, History and GIS: Epistemologies, Considerations and Reflections, (United States 2012), 153-171.

${ }^{31}$ T. Cresswell, 'Towards a Politics of Mobility', Environment and Planning D: Society and Space 28 (2010), 17-31. Cited here at 19.

${ }^{32}$ That sealed roads are safer than dirt is a taken-for-granted assumption permeating road discourses internationally. In the Australian context extensive literature produced by Australian State and National Road Departments, and multiple publicity campaigns waged over the last century by the NRMA all paint a similar picture. 
${ }^{33}$ S. Redshaw, In the Company of Cars: Driving as a Social and Cultural Practice (London, 2008).

${ }^{34}$ I. Gregory, 'Exploiting Time and Space: A Challenge for GIS in the Digital Humanities', in D.

Bodenhamer, J. Corrigan, and T. Harris, eds, The Spatial Humanities: GIS and the Future of

Humanities Scholarship, (Indiana 2010), 58-76. Cited here at 70.

${ }^{35}$ Bowles, 'Limit of Maps? Locality and Cinemagoing in Australia', 90. 